\title{
Spontaneous bilateral carpopedal spasm in a bulimic patient
}

\author{
Niranjan Tachamo, ${ }^{1}$ Bidhya Timilsina, ${ }^{2}$ Saroj Lohani, ${ }^{3}$ Salik Nazir ${ }^{3}$
}

'Department of Internal Medicine, Reading Health System, Pennsylvania, USA ${ }^{2}$ Department of Internal Medicine, Reading Health System, Pennsylvania, USA ${ }^{3}$ Department of Internal Medicine, Reading Hospital and Medical Center, Pennsylvania, USA

\section{Correspondence to}

Dr Niranjan Tachamo, niranjantachamo@gmail.com

Accepted 28 September 2017

\section{DESCRIPTION}

A 36-year-old woman presented to the emergency department after she woke up with painful spasm of bilateral hands. She had been vomiting 10-15 times daily for the past few days. She denied any laxative or diuretic abuse. She had 18-year history of bulimia nervosa, primarily involving self-induced vomiting and excessive exercising. Her body mass index was $20.7 \mathrm{~kg} / \mathrm{m}^{2}$. Vital signs and physical examination were unremarkable except for dry oral mucosa, poor oral dentition and classic bilateral carpopedal spasm (figure 1). Labs revealed hypocalcaemia (ionised calcium $0.88 \mathrm{mmol} / \mathrm{L}$ ), hypokalaemia (potassium $2.8 \mathrm{mEq} / \mathrm{L}$ ), hypomagnesaemia (magnesium $1.6 \mathrm{mEq} / \mathrm{L}$ ),

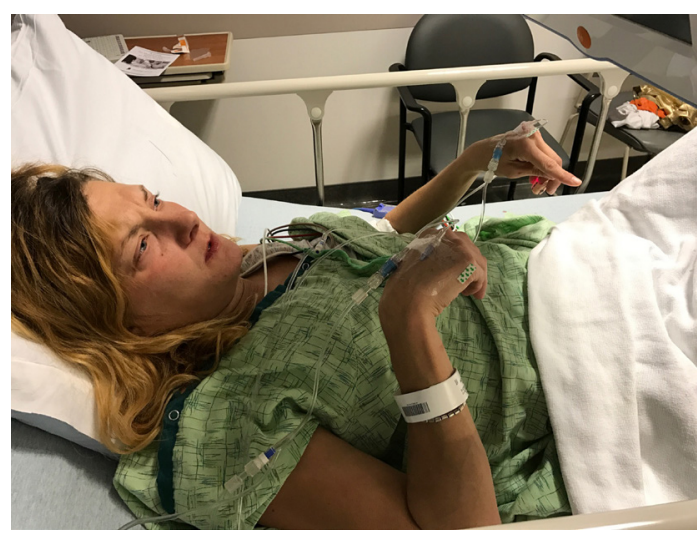

Figure 1 Spontaneous bilateral carpopedal spasm. metabolic alkalosis (serum bicarbonate 34.5 $\mathrm{mEq} / \mathrm{L}$ ), hypochloraemia (chloride $78 \mathrm{mEq} / \mathrm{L}$ ), hypophosphataemia (phosphorus $1.6 \mathrm{mg} / \mathrm{dL}$ ), acute kidney injury (serum creatinine $2.49 \mathrm{mg}$ / $\mathrm{dL}$, baseline of 0.9), leucocytosis (white blood cells $15700 \times 10^{9} / \mathrm{L} \mathrm{mm}^{3}$ ) and normal serum albumin $4 \mathrm{~g} / \mathrm{dL}$. ECG showed normal sinus rhythm with prolonged QTc of $550 \mathrm{~ms}$ (figure 2). Urine drug screen was positive for cocaine. She was resuscitated with intravenous fluids and repleted with electrolytes, leading to resolution of her carpopedal spasm, leucocytosis, electrolyte and ECG abnormalities.

Tetany is a syndrome characterised by painful flexion of wrist and ankle joints (carpopedal spasm), muscle cramps, twitching, seizure, laryngospasm, syncope or myocardial dysfunction. It occurs due to hyperexcitable nerves and muscles in the setting of decreased extracellular ionised calcium. ${ }^{1}$ Bulimia nervosa, to the extent of causing spontaneous carpopedal spasm, has not been reported in literature. Bulimia is an eating disorder characterised by recurrent episodes of binge eating and inappropriate compensatory behaviours like self-induced vomiting, laxative or diuretic abuse. Bulimia occurs mostly in women (femaleto-male ratio of $10: 1){ }^{2}$ Acid-base and electrolyte disturbances are the most dangerous medical complications of bulimia and can result in death from cardiac arrhythmias. ${ }^{3}$ In bulimia, as in our patient, persistent vomiting

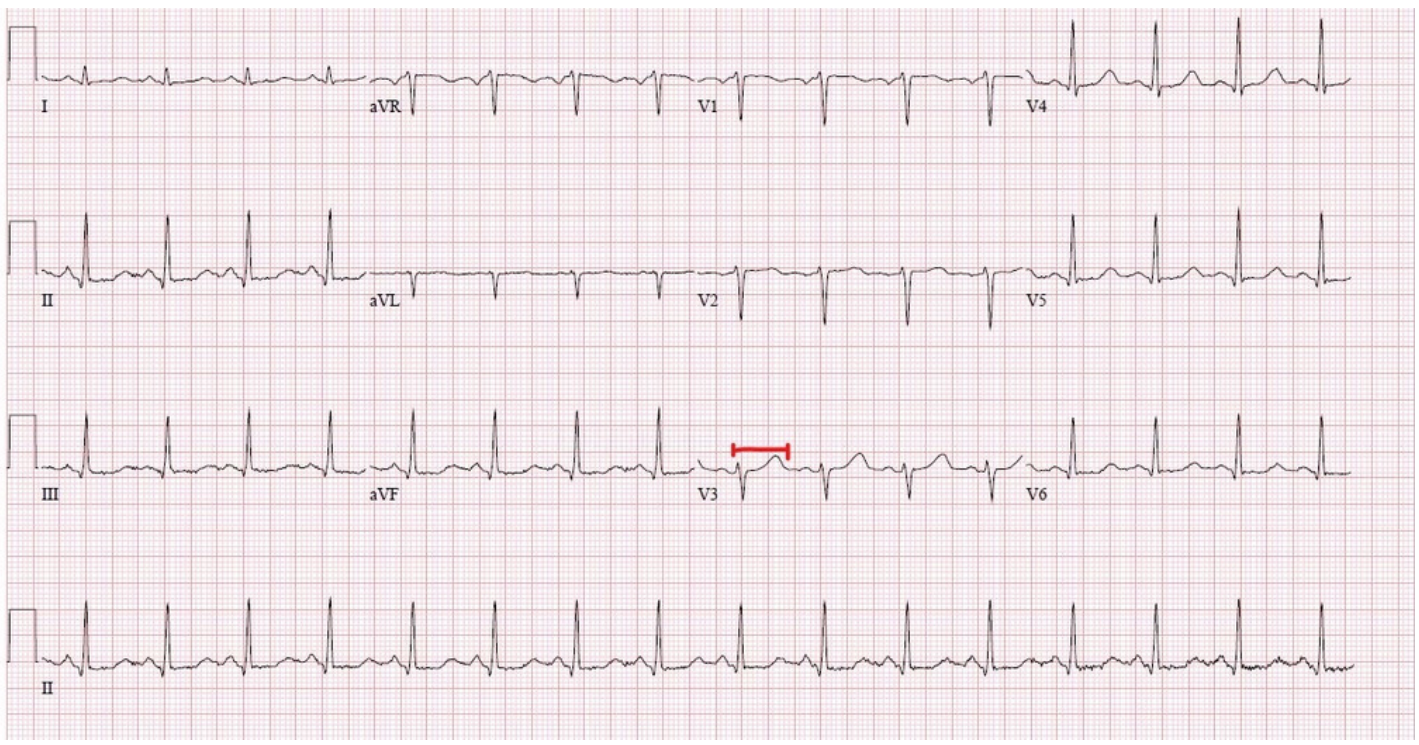

Figure 2 ECG showing prolonged QTc from hypocalcaemia. 
induces metabolic alkalosis and hypokalaemia due to loss of gastric acid and potassium in the vomitus. Alkalosis causes dissociation of hydrogen ion from albumin. As a result, calcium can bind to albumin causing decrease in free ionised calcium. Hypomagnesaemia occurs by similar mechanism. Hypokalaemia is worsened by intracellular shift of potassium due to alkalosis. Tetany can manifest from hypocalcaemia, hypomagnesaemia, hypokalaemia or alkalosis. ${ }^{1}$ Our patient had all four factors, which greatly increased the neuromuscular irritability and induced spontaneous carpopedal spasm. High index of suspicion may

\section{Learning points}

Spontaneous carpopedal spasm may occur in bulimic patients if severe acid-base and electrolyte disturbance occurs.

- Bulimia nervosa should always be considered in otherwise healthy women with unexplained hypokalaemia and metabolic alkalosis. be required to diagnose bulimia as the patient may not always admit it. Unexplained hypokalaemia when present in an otherwise healthy woman is highly specific for covert bulimia nervosa. ${ }^{3}$

Contributors NT: writing of the manuscript, concept and design. BT: editing of the manuscript. SL: direct patient care and provided images. SN: final revision of the manuscript.

Competing interests None declared.

Patient consent Obtained.

Provenance and peer review Not commissioned; externally peer reviewed.

(C) BMJ Publishing Group Ltd (unless otherwise stated in the text of the article) 2017. All rights reserved. No commercial use is permitted unless otherwise expressly granted.

\section{REFERENCES}

1 Parasa M, Saheb SM, Vemuri NN. Cramps and tingling: a diagnostic conundrum. Anesth Essays Res 2014;8:247-9.

2 American Psychiatric Association. Diagnostic and statistical manual of mental disorders. 5th edn. Arlington: American Psychiatric Publishing, 2013.

3 Westmoreland P, Krantz MJ, Mehler PS. Medical complications of anorexia nervosa and bulimia. Am J Med 2016;129:30-7.

Copyright 2017 BMJ Publishing Group. All rights reserved. For permission to reuse any of this content visit

http://group.bmj.com/group/rights-licensing/permissions.

BMJ Case Report Fellows may re-use this article for personal use and teaching without any further permission.

Become a Fellow of BMJ Case Reports today and you can:

- Submit as many cases as you like

- Enjoy fast sympathetic peer review and rapid publication of accepted articles

- Access all the published articles

- Re-use any of the published material for personal use and teaching without further permission

For information on Institutional Fellowships contact consortiasales@bmjgroup.com

Visit casereports.bmj.com for more articles like this and to become a Fellow 